\title{
Jaringan Syaraf Tiruan Perceptron untuk Pengenalan Pola Makanan Sehat Rendah Kolesterol
}

\author{
Nurul Khairina ${ }^{1}$, Muhammad Khoiruddin Harahap ${ }^{2}$ \\ ${ }^{1}$ Universitas Medan Area, Medan \\ ${ }^{2}$ Politeknik Ganesha Medan, Medan
}

nurulkhairina27@gmail.com ${ }^{1}$, choir.harahap@yahoo.com²

\begin{abstract}
With the computer, the computing process has become easier. Computers are used to model the biological nerves of the human brain, computers are trained and are taught how to act as human nerve cells capable of recognizing simple patterns. The artificial neural network is able to recognize the input pattern and will issue output in accordance with the target to be achieved. In this research Perceptron method is used to recognize the input pattern in the form of healthy food low cholesterol. This method works by adjusting the input with the target and doing the weight changes until there are no more errors found in each epoch. The result of the introduction of low cholesterol diet was found that egg whites, freshwater fish, and cheese were foods that contained low to moderate cholesterol levels. However, quail eggs are foods that contain high cholesterol levels..
\end{abstract}

Keyword : neural networks, perceptron, cholesterol.

\begin{abstract}
Abstrak
Dengan adanya komputer, proses komputasi sudah menjadi lebih mudah. Komputer digunakan untuk memodelkan syaraf biologis otak manusia, komputer dilatih dan diajarkan bagaimana berperan selayaknya sel syaraf manusia yang mampu mengenali pola-pola sederhana. Jaringan syaraf tiruan mampu mengenali pola masukan dan akan mengeluarkan output yang sesuai dengan target yang ingin dicapai. Pada penelitian kali ini metode Perceptron digunakan untuk mengenali pola masukan yang berupa makanan sehat rendah kolesterol. Metode ini bekerja dengan menyesuaikan input dengan target dan melakukan perubahan bobot sampai tidak ada lagi ditemukan error pada setiap epoch nya. Hasil dari pengenalan pola makanan rendah kolesterol ini diperoleh bahwa putih telur, ikan air tawar, dan keju adalah makanan yang mengandung kadar kolesterol rendah sampai sedang. Namun telur puyuh merupakan makanan yang mengandung kadar kolesterol tinggi.
\end{abstract}

Kata Kunci : jaringan syaraf tiruan, perceptron, kolesterol

\section{Pendahuluan}

Kesehatan menjadi kunci utama dalam kehidupan, jika kondisi fisik jasmani seseorang sehat maka akan mudah menjalani berbagai aktivitas sehari-hari, dan juga sebaliknya jika kondisi fisik jasmani seseorang tidak sehat maka sudah pasti akan menghambat aktivitas sehari-hari.

Ada banyak penyebab menurunnya kondisi fisik jasmani seseorang, pada umumnya dikarenakan faktor cuaca, virus, bakteri, kurangnya istirahat, tidak ada waktu untuk berolahraga, makan tidak tepat waktu dan tidak mengkonsumsi makanan yang sehat.

Anak muda dan para pekerja sering sekali mengabaikan pola makanan yang sehat, faktor ketidaktahuan dan tidak adanya waktu untuk memilih dan mengkonsumsi makanan yang sehat, menjadi faktor utama penyebab rentannya fisik kita terhadap penyakit.

Bagi anak muda, mengkonsumsi makanan yang kurang sehat memang tidak langsung memberikan dampak, namun bisa berdampak di hari tua, sebaliknya bagi orangtua, mengkonsumsi makanan yang kurang sehat dapat langung memberikan dampak yang besar. Bagi orangtua yang sudah berumur diatas 40 tahun pada umumnya sudah mulai berpikir untuk menjaga makanan dan mengkonsumsi pola makanan yang sehat. 
Salah satu ciri-ciri dari pola makanan yang sehat adalah rendahnya kandungan kolesterol pada sebuah makanan. Makanan yang sehat pasti mengandung tingkat kolesterol yang rendah ataupun sedang, selebihnya jika tingkat kolesterol yang terkandung di dalam makanan tergolong tinggi, maka lebih baik makanan tersebut tidak dikonsumsi.

Pada zaman yang sudah maju seperti sekarang ini, pengetahuan tentang kandungan kolesterol yang terdapat di dalam makanan tidak sulit lagi untuk didapatkan, dengan membeli buku kesehatan seseorang sudah dapat mengetahui apa saja makanan yang boleh dikonsumsi atau tidak boleh dikonsumsi.

Algoritma Perceptron merupakan algoritma sederhana yang sering digunakan untuk mengenali sebuah pola masukan, seperti yang dilakukan oleh Kukuh (Yudhistiro, 2017), metode jaringan syaraf tiruan Perceptron digunakan untuk mengenali pola huruf abjad.

Berdasarkan latar belakang yang telah dipaparkan sebelumnya, kali ini penulis ingin melakukan uji coba pengenalan pola makanan sehat rendah kolesterol menggunakan metode Jaringan Syaraf Tiruan Perceptron.

\section{Landasan Teori}

\section{A. Sistem Syaraf Manusia}

Pada sistem syaraf manusia terdapat sel syaraf (neuron). Neuron berfungsi mengirim rangsangan dari panca indra menuju otak. Berikut ini beberapa istilah penting pada sel syaraf manusia :

$\begin{array}{ll}\text { a. } & \text { Dendrit } \\ \text { b. } & \text { Badan Sel } \\ \text { c. Nukleus } \\ \text { d. Neurit } \\ \text { e. Selubung Mielin } \\ \text { f. Sel Schwann }\end{array}$

g. Sinapsis (Suparman, 2007).

: Berfungsi membawa rangsangan ke badan sel.

: Berfungsi membawa rangkasan ke akson.

: Berfungsi mengatur kegiatan neuron.

: Berfungsi membawa rangsangan dari badan sel ke neuron.

: Berfungsi untuk membungkus dan melindungi akson dari kerusakan.

: Berfungsi menyediakan makanan untuk neurit dan berperan dalam regenerasi Neurit.

: Berfungsi menghubungkan sebuah neurit dengan neurit dari neuron lainnya

Berikut ini ilustrasi system syaraf manusia :

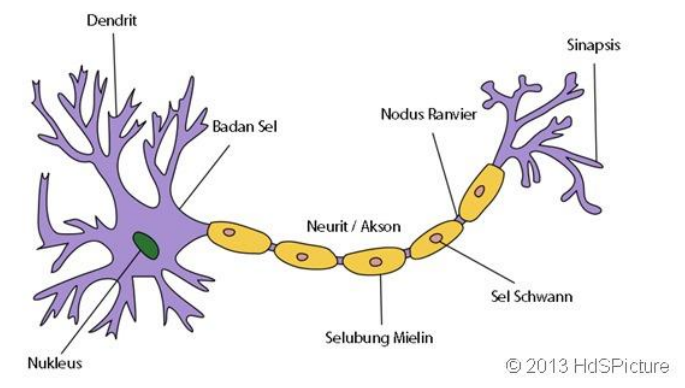

Gambar 1. Sistem Syaraf Manusia

\section{B. Jaringan Syaraf Tiruan}

Jaringan Syaraf Tiruan merupakan teknik mengelola informasi yang berbasis komputasi yang memodelkan sistem syaraf biologis manusia (Suparman, 2007). Jaringan Syaraf Tiruan memanfaatkan teknologi dimana komputer diprogram untuk dapat meniru cara kerja system syaraf manusia. Pada otak manusia, syaraf memiliki banyak fungsi, salah satunya adalah mengenali sebuah objek. Dalam Jaringan Syaraf Tiruan, komputer akan diajarin untuk mengenali pola sampai akhirnya dapat mengenali sebuah objek 


\section{Kolesterol}

Kolesterol merupakan tanda bahwa terdapat jumlah lemak yang berlebih di dalam tubuh manusia. Terdapat 2 jenis kolesterol, yaitu kolesterol jahat yang dikenal dengan LDL (Low Density Lipoprotein) dan kolesterol baik yang dikenal dengan HDL (High Density Lipoprotein) (Nilawati, 2008) .

Semua jenis makanan belum tentu sehat apabila dikonsumsi terus menerus, makanan rendah kolesterol mungkin aman apabila dikonsumsi terus-menerus, sedangkan makanan dengan tingkat kolesterol yang cukup tinggi sudah perlu berhati-hati dalam mengkonsumsinya, karena makanan ini sangat berbahaya untuk kesehatan. Tidak jarang kadar kolesterol yang tinggi dapat mengakibatkan penyakit jantung coroner (Tri \& Hatta, 2011).

Berikut ini jenis-jenis makanan rendah kolesterol dan tinggi kolesterol menurut para ahli gizi (Nilawati, 2008) :

Tabel 1

Daftar Makanan Rendah Kolesterol dan Tinggi Kolesterol

\begin{tabular}{|c|c|}
\hline \multirow{2}{*}{ Jenis Makanan } & Kolestrol \\
\hline & $(\mathrm{Mg} / 10 \mathrm{gr})$ \\
\hline \multicolumn{2}{|c|}{ Aman Dikonsumsi } \\
\hline Putih telur ayam & 0 \\
\hline Teripang & 0 \\
\hline Susu sapi non fat & 0 \\
\hline Daging ayam tanpa kulit & 50 \\
\hline Ikan air tawar & 22 \\
\hline Daging sapi tanpa lemak & 60 \\
\hline Daging kelinci & 65 \\
\hline Daging kambing tanpa lemak & 70 \\
\hline Ikan ekor kucing & 85 \\
\hline \multicolumn{2}{|c|}{ Boleh Dikonsumsi Sekali-Sekali } \\
\hline Daging asap & 98 \\
\hline Iga sapi & 100 \\
\hline Daging sapi & 105 \\
\hline Burung dara & 120 \\
\hline Ikan bawal & 120 \\
\hline \multicolumn{2}{|c|}{ Perlu Berhati-hati Saat Mengkonsumsi } \\
\hline Daging sapi berlemak & 125 \\
\hline Gajih sapi & 130 \\
\hline Gajih kambing & 130 \\
\hline Keju & 140 \\
\hline Sosis daging & 150 \\
\hline Kepiting & 150 \\
\hline Udang & 160 \\
\hline Siput & 185 \\
\hline \multicolumn{2}{|c|}{ Berbahaya Dikonsumsi } \\
\hline Santan & 185 \\
\hline Susu sapi non fat & 250 \\
\hline \begin{tabular}{|l|} 
Susu sapi cream \\
\end{tabular} & 280 \\
\hline Coklat & 290 \\
\hline \begin{tabular}{|l|} 
Margarin \\
\end{tabular} & 300 \\
\hline \begin{tabular}{|l} 
Jeroan sapi \\
\end{tabular} & 380 \\
\hline Kerang putih/ tiram & 450 \\
\hline \begin{tabular}{|l|} 
Jeroan kambing \\
\end{tabular} & 610 \\
\hline \begin{tabular}{|l} 
Cumi-cumi \\
\end{tabular} & 1170 \\
\hline Kuning telur ayam & 2000 \\
\hline \begin{tabular}{|l|} 
Otak sapi \\
\end{tabular} & 2300 \\
\hline Telur burung puyuh & 3640 \\
\hline
\end{tabular}

\section{Metode Perceptron}

Metode perceptron merupakan metode yang memiliki kinerja yang baik. Perceptron ditemukan oleh Rosenblatt pada tahun 1962 dan kemudian dikembangkan lagi oleh Minsky-Papert pada tahun 1969 (Panjaitan, 2007). Berikut ini model Jaringan Syaraf Tiruan metode Perceptron : 


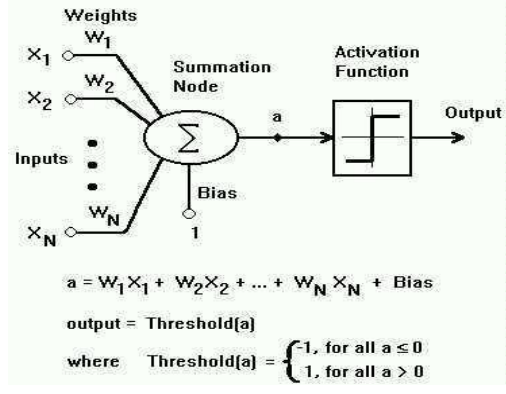

Gambar 2. Model Jaringan Metode Perceptron

\section{Metodologi Penelitian}

\section{A. Metode Perceptron}

Metode Perceptron ini biasanya dipakai untuk mengklasifikasikan suatu pola tertentu. Berikut ini langkah-langkah pembelajaran Perceptron :

a. Tentukan bobot awal dan bias sama dengan 0 ,

b. Tentukan Learning Rate $(\propto)$ antara 0 sampai 1 ,

c. Selama kondisi pembelajaran berhenti dan bernilai false, maka :

a) Set input dengan nilai sama dengan vector input $x_{i}=S_{i j}$

b) Hitung respon untuk unit output: $\mathrm{x}_{\mathrm{i}} \cdot \mathrm{w}_{\mathrm{i}}$

$$
\begin{gathered}
\text { y_in }=x 1 . w 1+x 2 . w 2+\ldots \ldots+x n \cdot w n+b \\
\text { fnet }=\left\{\begin{array}{rc}
1 & \text { y_in }>\theta \\
0 & -\theta \leq y \_ \text {in } \leq \theta \\
-1 & \text { y_in }<\theta
\end{array}\right.
\end{gathered}
$$

c) Perbaiki bobot dan bias jika terjadi error :

Jika $\mathrm{y} \neq \mathrm{t}$ maka :

$$
\begin{array}{ll}
\mathrm{w}_{\mathrm{i}}(\text { baru }) & =\mathrm{w}_{\mathrm{i}}(\text { lama })+\infty^{*} \mathrm{t} * \mathrm{x} \\
\mathrm{b}(\text { baru }) & =\mathrm{b}(\text { lama })+\infty^{*} \mathrm{t}
\end{array}
$$

Jika tidak, maka :

$$
\begin{array}{ll}
\mathrm{w}_{\mathrm{i}} \text { (baru) } & =\mathrm{w}_{\mathrm{i}} \text { (lama) } \\
\mathrm{b} \text { (baru) } & =\mathrm{b} \text { (lama) }
\end{array}
$$

d.Tes kondisi berhenti : jika tidak terjadi perubahan bobot maka kondisi berhenti true, namun jika masih terjadi perubahan maka kondisi berhenti false (Yudhistiro, 2017).

\section{Pembahasan}

Pada penelitian kali ini, diambil empat sampel makanan dari seluruh jenis makanan yang ada, yaitu :

1. Putih telur

2. Ikan air tawar

3. Keju

4. Telur puyuh

Pada jaringan syaraf tiruan, empat sampel makanan diatas akan dipakai sebagai input-an yang akan dilatih untuk mencapai target yang ditentukan di dalam jaringan Perceptron yang akan dibangun. 
Kita asumsikan empat input-an tersebut sebagai $\mathrm{x} 1, \mathrm{x} 2, \mathrm{x} 3$, dan $\mathrm{x} 4$. Target yang harus dicapai diasumsikan dalam bentuk yang sama dengan inputan, yaitu 0 dan 1.

- Nilai 0 menyatakan makanan rendah sampai sedang kolesterol,

- Nilai 1 menyatakan makanan tinggi kolesterol.

Tabel 2 Input Jaringan

\begin{tabular}{|c|c|c|c|c|}
\hline $\mathrm{x} 1$ & $\mathrm{x} 2$ & $\mathrm{x} 3$ & $\mathrm{x} 4$ & Target \\
\hline 0 & 0 & 0 & 1 & 0 \\
\hline 0 & 0 & 1 & 1 & 0 \\
\hline 0 & 1 & 1 & 1 & 0 \\
\hline 1 & 1 & 1 & 1 & 1 \\
\hline
\end{tabular}

Kemudian, kita tentukan bobot awal, bias (b), alpha $(\propto)$, threshold $(\theta)$, fnet, seperti yang dijabarkan dibawah ini :
a. Bobot $=w 1=0 ; \quad w 2=0 ; \quad w 3=0$;
b. bias (b) $=0$
c. alpha $(\propto)=1$
d. threshold $(\theta)=15$
e. fnet $=$

$$
\text { fnet }=\left\{\begin{array}{rc}
1 & \text { y_in }>15 \\
0 & -15 \leq \text { y_in } 15 \\
-1 & \text { y_in }<15
\end{array}\right.
$$

Setelah menentukan bobot, bias (b), alpha $(\propto)$, threshold $(\theta)$, dan fnet maka jaringan Perceptron dapat dibangun. Pada proses pembelajaran (learning) terjadi banyak perubahan bobot untuk bisa mendapatkan output yang sesuai dengan target.

Berikut proses pembelajaran yang terjadi sampai jaringan dapat menemukan kesamaan antara output dan target :

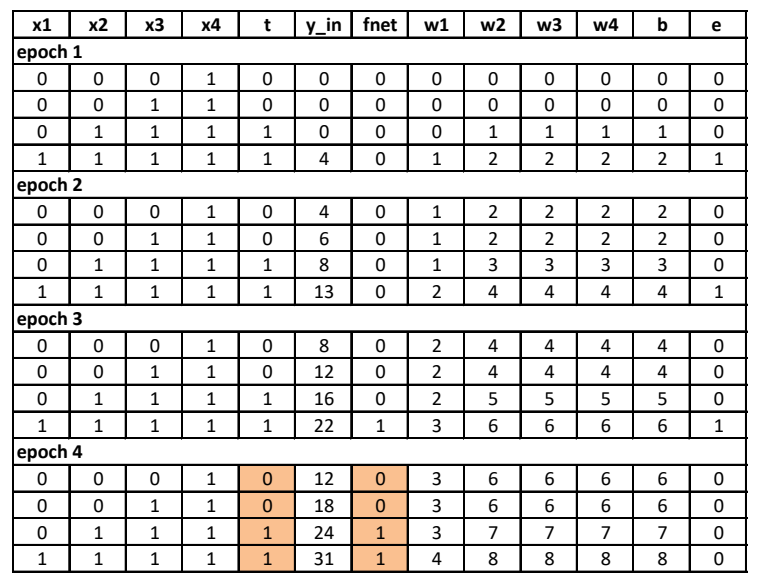

Gambar 2. Proses Pembelajaran Perceptron

Pada proses pembelajaran, jaringan akan berhenti berproses apabila jaringan sudah menemukan kesamaan antara output (fnet) dan target (t).

Pada epoch ke -4 tampak bahwa bobot awal $\mathrm{w} 1=0, \mathrm{w} 2=0, \mathrm{w} 3=0$ dan $\mathrm{w} 4=0$, kini sudah berubah menjadi $\mathrm{w} 1=4, \mathrm{w} 2=8, \mathrm{w} 3=8$, dan $\mathrm{w} 4=8$. Perubahan error juga dapat dilihat pada setiap epoch nya, pada epoch ke - 1, 2 dan 3 masih terdapat error, namun pada epoch ke - 4 semua nilai error sudah menjadi 0, ini membuktikan bahwa jaringan sudah berhasil melakukan pembelajaran dan tidak terdapat lagi error, sehingga proses pembelajaran dapat dihentikan. 
Proses pembelajaran diatas memiliki arti bahwa jaringan dapat mengenali input-an $\mathrm{x} 1, \mathrm{x} 2, \mathrm{x} 3$ dan $\mathrm{x} 4$ dengan baik sehingga bisa mengeluarkan output yang sesuai dengan target yang ingin dicapai tanpa adanya error. Kalau kita kaitkan hasil output dengan target yang telah tercapai, maka dapat dikatakan bahwa makanan putih telur, ikan air tawar, dan keju adalah makanan dengan kadar kolesterol rendah sampai sedang, namun telur puyuh adalah makanan dengan kadar kolesterol tinggi.

\section{Kesimpulan \& Saran}

\section{A. Kesimpulan}

Berikut ini adalah kesimpulan terhadap uji coba yang dilakukan :

1. Metode Perceptron mampu melakukan pengujian pengenalan pola makanan sehat rendah kolesterol dan tinggi kolesterol dengan baik, metode ini mengenali inputan dengan baik sehingga bisa melakukan perubahan bobot untuk memperoleh output yang sesuai dengan target yang ingin dicapai.

2. Setelah melakukan perubahan bobot berulang kali, pada epoch ke - 4 jaringan Perceptron mampu mengeluarkan output yang sama dengan target dengan tidak ada lagi error yang ditemukan.

\section{B. Saran}

Adapun saran terhadap penelitian ini adalah :

1. Perlunya menggunakan metode jaringan syaraf lainnya seperti adeline, madeline maupun backpropagation untuk membandingkan hasil pengenalan pola terhadap inputan,

2. Perlu adanya variabel pengujian yang lain untuk dapat mengenali pola lebih baik.

\section{Referensi}

[1] Nilawati, S., 2008. Care Your Self Kolesterol. Jakarta : Penebar Plus.

[2] Panjaitan, L. W., 2007. Dasar-dasar Komputasi Cerdas. Yogyakarta: Andi.

[3] Suparman, M., 2007. Komputer Masa Depan Pengenalan Artificial Intelligence. Yogyakarta: Andi.

[4] Tri, A. \& Hatta, H. R., 2011. Probabilistic Fuzzy Neural Network untuk Deteksi Dini Penyakit Jantung Koroner. Jurnal Informatika Mulawarman, 6(2), pp. 75-80.

[5] Yudhistiro, K., 2017. Pemanfaatan Neural Network Perceptron. Journal of Information Technology and Computer Science (JOINTECS), 2(2), pp. 83-86. 